\title{
Regeneração de plantas a partir de dois tipos de explantes de milho submetidos à transformação genética por biobalística
}

\author{
Regeneration of plants from two types of maize explants submitted to transformation by biolistic
}

\author{
Tiago Mateus Andrade Vidigal $^{*}$ Ivan Schuster ${ }^{\mathrm{I}, \text { II }}$ Leandra Regina Texeira ${ }^{\text {II }}$ \\ Nelson Barros Colauto ${ }^{\mathrm{I}}$
}

\section{RESUMO}

O uso da biobalística na transformação genética de plantas requer a otimização de diversos parâmetros, entre eles, o desenvolvimento de protocolos para regeneração de plantas a partir de células transformadas. Este trabalho teve como objetivo avaliar a eficiência de regeneração de plantas de milho a partir de calos embriogênicos e de explantes sementes divididas, submetidos à transformação por biobalística, utilizando $o$ gene bar como marcador de seleção. Foram submetidos 2000 agrupamentos de calos embriogênicos de milho e 2000 explantes sementes divididas à transformação por biobalística. A seleção dos eventos de transformação foi realizada em meios de cultivo suplementados com glifosinato de amônio. As plântulas selecionadas foram aclimatadas e transplantadas para vasos em casa de vegetação. Com a utilização de embriogênese somática, a eficiência de regeneração foi de 0,2\%, enquanto que, com a utilização de sementes divididas, a eficiência de regeneração foi de 1,3\%. Embora ambos os protocolos possibilitem a regeneração de plantas de milho submetidas à transformação por biobalística, há a necessidade de aumentar sua eficiência.

Palavras-chave: milho, embriogênese somática, sementes divididas, transformação genética, gene bar.

\section{ABSTRACT}

The use of biolistic on genetic transformation of plants requires an optimization of several parameters, including the protocol development for plant regeneration from transformed cells. The objective of this research was to evaluate the regeneration efficiency of maize plants from embryogenic callus and explants from split seeds submitted to transformation by biolistic using the gene bar as a selectable marker. It was submitted 2000 clusters of embryogenic callus and 2000 divided maize seeds to transformation by biolistic. The selection of transformation events was in culture medium supplemented with ammonium glifosinate. Selected seedlings were acclimatized and transplanted to pots in a greenhouse. Using somatic embryogenesis, the regeneration efficiency was $0.2 \%$, while using split seeds explants the regeneration efficiency was $1.3 \%$. Although both protocols allow the maize plant regeneration after transformation by biolistic, there is a need to increase its efficiency.

Key words: maize, somatic embryogenesis, split-seeds, genetic transformation, gene bar.

\section{INTRODUÇÃO}

Em geral, os protocolos de transformação genética de plantas baseiam-se na introdução de ácidos nucleicos em células vegetais totipotentes, seguida da regeneração destas células em plantas férteis (ONETO et al., 2010). Este processo depende da capacidade de proliferação e regeneração dos tecidos transformados em meios de seleção suplementados com herbicidas (SAHRAWAT et al., 2003). Genes marcadores de seleção são utilizados para selecionar as células transformadas no meio de cultivo (NEUMANN et al., 2009). Para a transformação genética de milho, o marcador de seleção mais utilizado é o gene bar, que codifica para a enzima fosfinotricina acetiltransferase, resistente a herbicidas (WANG et al., 2009).

Dentre os diversos métodos de transformação genética, a transformação mediada por agrobactérias e biobalística tem apresentado maior eficiência e aplicabilidade (WANG et al., 2009). Entretanto, para plantas monocotiledôneas, a biobalística tem sido o método de escolha na maioria dos laboratórios (KOMARI et al., 1998).

IMestrado em Biotecnologia Aplicada à Agricultura, Universidade Paranaense (UNIPAR), 87502-210, Umuarama, PR, Brasil. E-mail: tiagomvidigal@yahoo.com.br. *Autor para correspondência.

IICooperativa Central de Pesquisa Agrícola (COODETEC), Cascavel, PR, Brasil. 
O desenvolvimento de protocolos de regeneração de plantas completas a partir de células individuais capazes de serem transformadas com alta frequência, velocidade de regeneração, estabilidade genômica, independente do genótipo utilizado, vem sendo o principal objetivo dos grupos de pesquisa que trabalham com biotecnologia em plantas (SAIRAM et al., 2008). Os tecidos primários mais eficientes na regeneração de plantas por embriogênese somática são os embriões imaturos obtidos de genótipos capazes de produzir calos embriogênicos do tipo II (BRETTSCHNEIDER et al., 1997; KOMARI, et al., 1998; SAHRAWAT et al., 2003; WANG et al., 2009). Estes calos são friáveis, amarelados, de consistência macia, podem ser mantidos em cultivo in vitro por maior tempo (GREEN et al., 1983). Estes tecidos apresentam maior eficiência na transformação e regeneração em milho por apresentarem elevada atividade embriogênica (GRANDO et al., 2013), o que lhes confere a capacidade de proliferar rapidamente e contribui para maior propagação do tecido transformado (AULINGER et al., 2002).

Uma metodologia alternativa à embriogênese somática é a utilização de sementes divididas. $\mathrm{O}$ uso deste tipo de explante independe do genótipo quanto à eficiência para a regeneração de plantas por meio de embriogênese somática ou organogênese direta. Plantas de milho foram regeneradas a partir de sementes divididas por ALABED et al. (2006), AL-ABED et al. (2007) e por RAZI \& RAHNAMA (2012).

Uma das principais limitações dos métodos de transformação genética está relacionada ao processo de regeneração de plantas a partir de células em cultura de tecidos, restringindo as espécies de milho que são passíveis de manipulação genética (ONETO et al., 2010). Portanto, há necessidade de estabelecer e/ou otimizar protocolos de transformação genética para cada genótipo e avaliar sua eficiência. Este trabalho teve como objetivo avaliar a eficiência de regeneração de plantas de milho a partir de embriões imaturos, produtores de calos embriogênicos e de sementes divididas de milho, submetidas à transformação por biobalística, utilizando o gene bar como marcador de seleção.

\section{MATERIAL E MÉTODOS}

Embriogênese somática

Nos experimentos de avaliação da regeneração de explantes a partir de embriogênese somática submetidos à transformação por biobalística, foram utilizadas plantas de milho da linhagem
LD82025. FERNANDES et al. (2008) investigaram 11 genótipos de milho quanto à capacidade de formação de calos embriogênicos e capacidade de regeneração de plantas em cultura de tecidos. Nos genótipos LD82025, CD308 e CML314, foram observados calos do tipo II, friáveis e embriogênicos. O genótipo LD82025 foi o que apresentou maior número de plantas que resistiram ao processo de aclimatação: 4,34 $\pm 4,50$.

Para a obtenção dos embriões imaturos, as plantas foram cultivadas em casa de vegetação vegetação. De 14 a 18 dias após a autopolinização as espigas cujos grãos apresentavam aspecto leitoso foram colhidas para a retirada dos embriões imaturos. As espigas foram imersas em etanol $70 \%$, por $15 \mathrm{~min}$, imersas em hipoclorito de sódio a 2,5\% (v/v), contendo duas gotas por litro de Tween 20 a $0,01 \%$, por 20min, seguida de três lavagens sucessivas em água ultrapura autoclavada a $121^{\circ} \mathrm{C}$ por $30 \mathrm{~min}$. Com auxílio de bisturi, em câmara de fluxo laminar, foi realizado um corte longitudinal no topo dos grãos. Os embriões imaturos foram retirados com agulha histológica e colocados com o eixo embrionário em contato com o meio de cultivo. O eixo embrionário não foi removido. Foram posicionados 10 embriões em cada placa de Petri com meio de cultivo de iniciação. O Meio de iniciação utilizado, composto por sais N6 e vitaminas N6 (CHU et al., 1975), suplementado com $2 \%$ de sacarose, $1 \mathrm{mg} \mathrm{L}^{-1}$ de 2,4$\mathrm{D}$ (ácido 2,4 diclorofenoxiacético), $25 \mathrm{mM}$ de prolina, $100 \mathrm{mg} \mathrm{L}^{-1}$ de caseína hidrolisada, $10 \mathrm{mg} \mathrm{L}^{-1}$ de nitrato de prata, phytagel $^{\mathrm{TM}}$ (Sigma) a $0,4 \%$ e $\mathrm{pH}$ de 5,8 , conforme descrito por ARMSTRONG \& GREEN (1985).

As placas foram seladas e incubadas no escuro, a $27^{\circ} \mathrm{C}$, por 15 dias. Após este período, foram selecionadas nas placas as regiões dos explantes com a aparência de calos embriogênicos do tipo II, conforme GREEN et al. (1983),e transferidas para o meio de cultura de manutenção, contendo sais minerais e vitaminas N6 (CHU et al., 1975), contendo $2 \%$ de sacarose, $1 \mathrm{mg} \mathrm{L}^{-1}$ de 2,4-D (ácido 2,4 diclorofenoxiacético), 25mM de prolina, $100 \mathrm{mg} \mathrm{L}^{-1}$ de caseína hidrolisada, phytagel ${ }^{\mathrm{TM}}$ (Sigma) a $0,4 \%$ e $\mathrm{pH}$ de 5,8 . As placas foram seladas e incubadas no escuro a $27^{\circ} \mathrm{C}$, conforme proposto por JAKUBEKOVÁ et al. (2011). Após sete dias, os setores embriogênicos dos calos foram submetidos à transformação por biobalística.

Após o bombardeamento, os calos foram transferidos para o meio de cultivo de regeneração 1 (MR1) com sais minerais e vitaminas N6, 6\% de sacarose, $1 \mathrm{mg} \mathrm{L}^{-1}$ de ácido naftalenacético, phytagel ${ }^{\mathrm{TM}}$ a $0,4 \%$ e $\mathrm{pH}$ de 5,8. As placas foram seladas e 
incubadas no escuro a $27^{\circ} \mathrm{C}$ por 15 dias. Em seguida, os calos foram transferidos para o meio de cultura de regeneração 2 (MR2), com sais minerais e vitaminas MS (MURASHIGE\&SKOOG, 1962), 2\% de sacarose, $2 \mathrm{~g} \mathrm{~L}^{-1}$ de myo-inositol, phytagel ${ }^{\mathrm{TM}}$ a $0,3 \%$ e pH de 5,8 . As placas foram seladas e incubadas sob foto período de $16 \mathrm{~h}$ de luz e intensidade luminosa de $30 \mu \mathrm{mol} \mathrm{m} \mathrm{m}^{-2}$ $\mathrm{s}^{-1}$ por 15 dias. A seleção dos calos transformados iniciou 30 dias após o bombardeamento, quando os calos foram transferidos para o meio de cultura de regeneração 3 (MR3), com metade da concentração de sais minerais e vitaminas MS, $2 \%$ de sacarose, $2 \mathrm{~g}$ $\mathrm{L}^{-1}$ de myo-inositol, phytagel ${ }^{\mathrm{TM}}$ a $0,4 \%, 1 \mathrm{mg} \mathrm{L}^{-1} \mathrm{de}$ glifosinato de amônio e $\mathrm{pH}$ de 5,8. O pH dos meios de cultura foi ajustado para 5,8 com hidróxido de potássio $(\mathrm{KOH})$ antes da autoclavagem a $121^{\circ} \mathrm{C}$ por $30 \mathrm{~min}$. As placas foram seladas e incubadas a $26^{\circ} \mathrm{C}$, sob fotoperíodo de $16 \mathrm{~h}$ de luz e intensidade luminosa de $30 \mu \mathrm{mol} \mathrm{m} \mathrm{m}^{-2} \mathrm{~s}^{-1}$, com subcultivo a cada 15 dias. As plântulas que desenvolveram parte aérea foram transferidas para MR3, suplementado com $1 \mathrm{mg} \mathrm{L}^{-1} \mathrm{de}$ ácido indol butírico para indução de raízes. Plântulas bem desenvolvidas foram transplantadas para vasos contendo solo e vermiculita (1:1), autoclavados por $30 \mathrm{~min}$ a $121^{\circ} \mathrm{C}$, e mantidas cobertas com sacos plásticos por sete a dez dias em incubadora a $26^{\circ} \mathrm{C}$ sob fotoperíodo de $16 \mathrm{~h}$ de luz e intensidade luminosa de $30 \mu \mathrm{mol} \mathrm{m} \mathrm{m}^{-2} \mathrm{~s} 1$, por 30 dias. Após este período, as plantas foram levadas para casa de vegetação e transplantadas em vasos contendo solo.

\section{Método de sementes divididas}

O método de sementes divididas é independente do genótipo, sendo dependente apenas do vigor das sementes. $\mathrm{Na}$ avaliação da regeneração de sementes divididas transformadas por biobalística foram utilizadas sementes maduras de milho da linhagem CP 59666, com vigor acima de $95 \%$ do banco de germoplasma da Cooperativa Central de Pesquisa Agrícola (Coodetec). As sementes contendo embriões imaturos foram desinfestadas da mesma forma que as espigas. Em seguida, as sementes foram submetidas a quatro lavagens sucessivas em água ultrapura autoclavada a $121^{\circ} \mathrm{C}$ por $30 \mathrm{~min}$ e depois embebidas em água ultrapura autoclavada a $121^{\circ} \mathrm{C}$ por $30 \mathrm{~min}$, por $24 \mathrm{~h}$. As sementes foram dissecadas de modo que o pericarpo e parte do tegumento foram removidos para que o embrião ficasse em contato direto com o meio de cultura de germinação, composto de MS básico adicionado de vitaminas $\mathrm{B}_{5}$ (GAMBORG et al.,1968), $30 \mathrm{~g} \mathrm{~L}^{-1}$ de sacarose, phytagel ${ }^{\mathrm{TM}}$ a $0,6 \%$ e $9 \mu \mathrm{mol} \mathrm{L^{-1 }}$ de 2,4-D, por dois a três dias. Foram cultivadas 10 sementes por placa.
Após o período de germinação, o eixo embrionário foi posicionado de modo que a semente fosse cortada longitudinalmente em duas metades iguais, usando pinças e bisturi. Em seguida, foram colocadas seis sementes divididas com a face cortada voltada para cima por $24 \mathrm{~h}$ em placa de Petri, contendo meio de cultura de indução de brotos (MIB), composto por sais MS, $1 \mathrm{mg} \mathrm{L}^{-1}$ de glicina, 400mg L $\mathrm{m}^{-1}$ de caseína hidrolisada, $30 \mathrm{~g} \mathrm{~L}^{-1}$ de sacarose suplementado com vitaminas $\mathrm{B}_{5}$, 17,6 $\mu \mathrm{mol} \mathrm{L} \mathrm{L}^{-1}$ de 6-benzilaminopurina, $9,2 \mu \mathrm{mol} \mathrm{L}{ }^{-1} \mathrm{de}$ cinetina e phytagel $^{\mathrm{TM}}$ a $0,7 \%$. Todas as placas utilizadas no bombardeamento foram abertas em câmara de fluxo laminar por três horas para secar as sementes divididas antes de serem submetidas à transformação genética pelo método de biobalística. Após transformação, os explantes foram transferidos para MIB por quatro dias, com fotoperíodo de $16 \mathrm{~h}$ de luz, a $26^{\circ} \mathrm{C}$, para recuperação, de acordo com o JAKUBEKOVÁ et al. (2011). Após quatro dias, os explantes foram transferidos para meio de cultura de seleção (MIB) suplementado com $5 \mathrm{mg} \mathrm{L}^{-1}$ de glifosinato de amônio. Os explantes foram subcultivados quinzenalmente para um novo meio de cultura seletivo antes da indução de raízes. Após esse período, potenciais transformantes foram cultivados em caixas magenta, contendo meio de cultura de enraizamento composto de sais MS com vitamina $\mathrm{B}_{5}$, contendo $30 \mathrm{~g}$

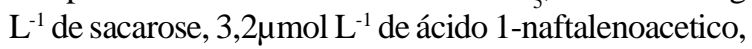
phytagel $^{\mathrm{TM}}$ a $0,7 \%$ e $3 \mathrm{mg} \mathrm{L}^{-1}$ de glifosinato de amônio, com objetivo de selecionar os transformantes antes de transferi-los para vasos em casa de vegetação. $\mathrm{O}$ pH dos meios de cultivo foi ajustado para 5,8 $\mathrm{KOH}$ antes da autoclavagem a $121^{\circ} \mathrm{C}$ por $30 \mathrm{~min}$. A aclimatação foi realizada da mesma forma que os explantes regenerados de embriogênese somática.

\section{Delineamento experimental}

Tanto para regeneração via embriogênese somática quanto para as sementes divididas, o delineamento experimental foi inteiramente casualizado, sendo que cada tratamento foi composto de 10 repetições, e cada repetição utilizou 10 explantes. A unidade experimental foi constituída de uma placa de Petri ou uma magenta, dependendo do desenvolvimento do explante. As plântulas obtidas foram sempre agrupadas pela unidade experimental inicial, ou seja, pela sua repetição. Uma vez que a variabilidade dentro dos tratamentos é grande neste tipo de experimento, os dados foram analisados apenas descritivamente.

Transformação genética

O projeto de transformação genética do milho foi aprovado pela Comissão Interna de 
Biossegurança da Coodetec sob número 503.003/12 e executada no laboratório de biotecnologia, sob Certificado de Qualidade em Biossegurança número 018/97. O plasmídio, vetor pJS107 (SU et al., 1998), utilizado em ambos os experimentos de transformação genética de milho, contém o gene marcador de seleção bar que codifica a enzima fosfinotricina acetil transferase e confere resistência ao herbicida glifosinato de amônio, sob o controle do promotor constitutivo P35S do vírus do mosaico da couve-flor. O gene bar possui também a sequência terminadora de transcrição do gene da nopalina sintase - TNOS de Agrobacterium. O vetor também possui o gene $p 5 \mathrm{cs}$, que codifica a enzima pirrolina-5-carboxilato sintetase de Vignaa conitifolia sob controle do promotor de estresse induzido AIPC (ABA inducible promoter complex). O promotor AIPC contém um elemento ANA responsivo (ABRC1) de 49pb do gene HVA22 de cevada (SHEN; HO, 1995), uma versão mínima de $180 \mathrm{pb}$ da região promotora do gene Actina 1 (pAct1$100)$ de arroz, a sequência de íntron de 233 pb do gene HVA22, e a sequência terminadora de transcrição (Pin-3') do gene inibidor II de protease de batata.

O DNA plasmidial foi isolado utilizando o kit Qiaprep Spin Miniprep ${ }^{\circledR}$ (Qiagen) com concentração ajustada para $1 \mu \mathrm{g} \mu \mathrm{L}^{-1}$. Neste experimento, foram utilizadas micropartículas de tungstênio. A suspensão de micropartículas foi preparada de acordo com a metodologia de SANFORD et al. (1993), sendo utilizado $50 \mu \mathrm{L}$ de micropartículas de tungstênio $(60 \mathrm{mg}$ $\left.\mathrm{mL}^{-1}\right), 8 \mu \mathrm{g}$ de DNA plasmidial, $50 \mu \mathrm{L}$ de $\mathrm{CaCl}_{2} 2,5 \mathrm{M} \mathrm{e}$ $20 \mu \mathrm{L}$ de espermidina $(0,1 \mathrm{M})$. Foram aplicados $3,2 \mu \mathrm{L}$ da suspensão de micropartículas na região central de cada membrana carreadora previamente posicionada no suporte. Os suportes contendo as membranas carreadoras foram posicionadas em um suporte contendo sílica gel e permaneceram em câmara de fluxo laminar para secagem. $\mathrm{O}$ equipamento de bombardeamento (Biomics ${ }^{\mathrm{TM}}$ ) foi usado com pressão de vácuo de $27 \mathrm{~mm}$ de mercúrio $(\mathrm{Hg})$. A distância entre a câmara de gás de alta pressão e a membrana carreadora contendo as micropartículas cobertas com DNA foi de $8 \mathrm{~mm}$ e a distância entre a membrana carreadora e a tela de retenção foi de $13 \mathrm{~mm}$. A pressão de ruptura de disco usada e a distância da prateleira (distância percorrida pela micropartícula até atingir o explante) foi de 1200 psi e de $90 \mathrm{~mm}$, respectivamente (RECH \& ARAGÃO, 1998).

\section{RESULTADOS E DISCUSSÃO}

Os dados obtidos a partir da regeneração das plantas foram submetidos ao teste de normalidade de LILLIEFORS (1967) e, por não atenderem às pressuposições básicas, não foi possível realizar testes estatísticos para os dados. Por esse motivo, os resultados foram analisados a partir de estatística descritiva.

Foram utilizados dois mil calos friáveis no experimento de transformação por biobalística a partir de embriogênese somática e regeneradas quatro plantas, correspondendo a uma frequência de regeneração de $0,2 \%$. Também foram utilizadas duas mil sementes divididas no outro experimento de transformação genética por biobalística com o mesmo vetor. As plântulas que não sobreviveram à seleção com glifosinato de amônio apresentaram coloração marrom. As plântulas potencialmente transformadas apresentaram elevado vigor, sugerindo a integração e funcionalidade do gene bar. Estas plântulas foram transferidas para vasos em câmara de crescimento. Foram regeneradas 26 plantas, utilizando sementes divididas, correspondendo a uma frequência de regeneração de $1,3 \%$.

O emprego de embriões imaturos de milho para indução de embriogênese somática e regeneração de plantas de milho submetidas à transformação por biobalística é frequente na literatura (GORDONKAMM et al., 1990; SONGSTAD et al., 1996; BRETTSCHNEIDER et al., 1997; ZHANG et al., 2012). De acordo com SONGSTAD et al. (1996), esse tipo de explante permite a obtenção de plantas transgênicas com elevada fertilidade em comparação a outros tipos de explantes.

A eficiência de regeneração de plantas de milho submetidas à transformação por biobalística é baixa em diversos trabalhos. PETRILO et al. (2008) bombardearam as culturas de embriões das linhagens de milho tropical L3 e L1345, com uma construção gênica contendo os genes bar e uidA, sob controle do promotor CAMV35S, as frequências de transformação do estudo variaram entre 0,9 e 2,31\%. SONGSTAD et al. (1996) bombardearam embriões imaturos do genótipo produtor de calos embriogênicos Hi-II e obtiveram uma frequência de regeneração de plantas transgênicas de $2 \%$, utilizando um gene de resistência ao herbicida clorosfurona como marcador de seleção. BRETTSCHNEIDER et al. (1997) submeteram à transformação por biobalística culturas de embriões imaturos dos genótipos H99; A188; Pa91; e dos cruzamentos A188 x H99 e Pa91 x H99. Neste trabalho, regeneraram plantas transgênicas para o gene marcador pat, que confere resistência ao herbicida Basta, a uma frequência entre 2 e 4\%. O'KENNEDY et al. (2001) submeteram culturas de embriões zigóticos das linhagens W506 
e M37 à transformação por biobalística e obtiveram frequência de regeneração de plantas transgênicas de $0,6 \%$, utilizando o gene bar como marcador de seleção. GORDON-KAMM et al. (1990) regeneraram plantas de milho positivas para o gene marcador bar com atividade da enzima PAT a partir de calos embriogênicos do tipo II, provenientes dos genótipos A188 x B73 e A188 X B84.

RAZI\&RAHNAMA(2012)bombardearam sementes divididas de milho do genótipo B73 e utilizaram o gene bar como marcador de seleção, sendo a frequência de regeneração de plantas no estudo de $1,8 \%$. AL-ABED et al. (2007) submeteram sementes divididas do genótipo R23 e ao bombardeamento de partículas e obtiveram frequência de regeneração de plantas transgênicas de 5\%, utilizando o marcador de seleção higromicina fosfotransferase.

A regeneração de plantas em meio seletivo sugere a integração e funcionalidade do gene marcador de seleção no tecido transformado. No entanto, a integração do transgene bar no genoma das plantas regeneradas não foi detectada por análise molecular nas plantas regeneradas. A baixa frequência de regeneração também pode estar associada aos genótipos de milho utilizados no trabalho. A ocorrência de calos embriogênicos friáveis do Tipo II é fator fundamental para sucesso no processo de regeneração in vitro. Entretanto, apenas um número limitado de genótipos de milho é capaz de expressar esta característica em meio de cultura. Genótipos que apresentam destaque para o desenvolvimento de calos embriogênicos friáveis do Tipo II, citados na literatura, são a linhagem A188 (ARMSTRONG \&GREEN, 1985) e o híbrido Hill (ARMSTRONG et al., 1991).

Os resultados obtidos no presente trabalho demonstram a possibilidade de regeneração de plantas de milho após a transformação de dois tipos de explantes por biobalística. As eficiências de regeneração de plantas obtidas a partir de embriões imaturos ou de explantes de sementes divididas submetidos à transformação por biobalística foi menor do que as eficiências comumente relatadas na literatura, indicando a necessidade de melhorar os protocolos utilizados.

\section{CONCLUSÃO}

A frequência de regeneração de plantas de milho a partir de calos embriogênicos friáveis submetidos à transformação por biobalística foi de $0,2 \%$; a frequência de regeneração utilizando sementes divididas no ensaio de transformação genética por biobalística foi de 1,3\%. Embora os protocolos utilizados possibilitem a regeneração de plantas de milho submetidas à transformação por biobalística, há a necessidade de aumentar a eficiência de regeneração.

\section{REFERÊNCIAS}

AL-ABED, D. et al. Genetic engineering of maize with the Arabidopsis dreb1a/cbf3 gene using split-seed explants. Crop Science, v.47, p.2390-2402, 2007. Disponível em: <https://www. crops.org/publications/cs/pdfs/47/6/2390>. Acesso em: 25 maio 2013.doi: 10.2135/cropsci2006.11.0712.

AL-ABED, D. et al. Split-seed: a new tool for maize researchers. Planta, v.223, p.1355-1360, 2006. Disponível em: <http://link. springer.com/article/10.1007\%2Fs00425-006-0237-9>. Acesso em: 25 maio 2013.doi: 10.1007/s00425-006-0237-9.

ARMSTRONG, C.L.; GREEN, C.E. Establishment and maintenance of friable, embryogenic maize callus and the involvement of L-proline. Planta, v.164, p.164-207, 1985. Disponível em: <http://link.springer.com/content/pdf/10.1007/ BF00396083.pdf>. Acesso em: 25 maio 2013. doi: 10.1007/ BF00396083.

ARMSTRONG, C.L. et al. Development and availability of germplasm with high type II culture formation response. Maize Genetics Cooperation Newsletter, v.65, p.92-93, 1991.

AULINGER, I.E. et al. Gametic embryos of maize as a target for biolistic transformation: comparison to immature zygotic embryos. Plant Cell Reports, v.21, p.585-591, 2002. Disponível em: <http://link.springer.com/article/10.1007\%2 Fs00299-002-0556-7>. Acesso em: 25 maio 2013. doi: 10.1007/ s00299-002-0556-7.

BRETTSCHNEIDER, R. et al. Efficient transformation of scutellar tissue of immature maize embryos. Theoretical and Applied Genetics, v.94, p.737-748, 1997.

CHU, C.C. et al. Establishment of an efficient medium for anther culture of rice through comparative of the nitrogen sources. Scientia Sinica, v.18, p.659-668, 1975.

DOYLE, J.J.; DOYLE, J.L. Isolation of plant DNA from fresh tissue. Focus, v.12, p.13-15, 1990.

FERNANDES, E.H. et al. Embriogênese somática a partir de embriões imaturos em genótipos de milho. Ciência Rural, v.9, p.2604-2607, 2008. Disponível em: <http://www.scielo.br/scielo. php script $=$ sci_arttext $\&$ pid $=$ S 01 03 $-84782008000900031>$. Acesso em: 25 maio 2013. doi: 10.1590/S0103-84782008000 900031.

GAMBORG, O.L. et al. Nutrient requirement of suspension cultures of soybean root cells. Experimental Cell Research, v.50, p.151-158, 1968.

GORDON-KAMM, W.J. et al. Transformation of maize cells and regeneration of fertile transgenic plants. Plant Cell, v.2, p.603-618, 1990. Disponível em: <http://www.plantcell.org/ content/2/7/603.full.pdf + html $>$. Acesso em: 25 maio 2013.doi: 10.1105/tpc.2.7.603. 
GRANDO, M.F. et al. Immature tassels as alternative explants in somatic embryogenesis and plant regeneration in south Brazilian maize genotypes. Acta Scientiarum Agronomy, v.16 p.39-47, 2013. Disponível em: <http://www.scielo.br/scielo. php?pid=S 1807-86212013000100005\&script $=$ sci_arttext $>$. Acesso em: 17 out. 2013.

GREEN, C. et al. Somatic cell genetic systems in corn. In: DOWNEY, K. et al. Advances in gene technology: molecular genetics of plants and animals. Nova York: Academic, 1983. p.147-157.

JAKUBEKOVÁ, M. et al. Somatic embryogenesis and plant regeneration from immature embrio induced callus of maize (Zea mayz L.). Journal of Microbiology, Biotechnology and Food Sciences, v.4, n.1, p.478-487, 2011.

KOMARI, T. et al. Advances in cereal gene transfer. Current opinion in plant biology, v.1, p.161-165, 1998. Disponível em: <http://www.ufv.br/dbv/pgfvg/BVE684/htms/pdfs_revisao/ trangenicos_transformacao/cerealtrafo.pdf $>$. Acesso em: 25 maio 2013. doi: 10.1016/S1369-5266(98)80019-8.

LILLIEFORS, H. On the Kolmogorov-Smirnov test for normality with mean and variance unknown. Journal of the American Statistical Association, v.62. p.399-402, 1967.

MURASHIGE, T.; SKOOG, F. A revised medium for rapid growth and bioassays with tobacco tissue culture. Physiologia Plantarum, v.15, p.473-497, 1962. Disponível em: <http:// onlinelibrary.wiley.com/doi/10.1111/j.1399-3054.1962. tb08052.x/pdf>. Acesso em: 25 maio 2013. doi: 10.1111/j.13993054.1962.tb08052.x.

NEUMANN, K. et al. Genetic problems and gene technology. In: NEUMANN, K. et al. Plant cell and tissue culture: a tool in biotechnology. Heidelberg: Springer, 2009. p.266-269.

O'KENNEDY, M. et al. Transformation of elite white maize using the particle inflow gun and detailed analysis of a lowcopy integration event. Plant Cell Reports, v.20, p.721-730, 2001.

ONETO, C.D. et al. Biolistic maize transformation: improving and simplifying the protocol efficiency. African Journal of Agricultural Research, v.5, p.3561-3570, 2010.
RAZI, Z.; RAHNAMA, H. Factors affecting delivery of DREB1A gene in maize B73 split seeds via biolistic system. Iranian Journal of Genetics and Plant Breeding, v.1, p.36-43, 2012.

RECH, E.L.; ARAGÃO, F.J.L. Biobalística. In: BRASILEIRO, A.C.M. Manual de transformação genética de plantas. Brasília: Embrapa SPI/Embrapa-Cenargen, 1998. Cap.3, p.51-64.

SAHRAWAT, A.K. et al. Genetic improvement of wheat via alien gene transfer, an assessment. Plant Science, v.165, p.1147-1168, 2003. Disponível em: <http://www.sciencedirect.com/science/ article/pii/S0168945203003236>. Acesso em: 25 maio 2013. doi:10.1016/S0168-9542(03)00323-6.

SAIRAM, R. et al. Maize. In: KOLE, C.; HALL, T.C. Compendium of transgenic crop plants: transgenic cereals and forage grasses. Oxford: Wiley-Blackwell, 2008. v.1, Cap.2, p.49-82.

SANFORD, J.C. et al. Optimizing the biolistic process for different biological applications. Methods in enzymology, v.217, p.483509, 1993. Disponível em: <http://www.sciencedirect.com/science/ article/pii/007668799317086K> . Acesso em: 29 maio 2013.

SHEN, Q.; HO, T.H.D. Functional dissection of an abscisic acid (ABA) - inducible gene reveals two independente $\mathrm{ABA}$ responsive complexes each containing a G-Box and a novel cis-acting element. Plant Cell, v.7, p.295-307, 1995.

SONGSTAD, D. et al. Production of transgenic maize plants and progeny by bombardment of hi-ii immature embryos. In vitro cellular \& developmental biology - plant, v.32, p.179-183, 1996. doi: 10.1007/BF02822763.

SU, J. et al. Dehydratation-stress-reguled transgene expression in stably transformed rice plants. Plant Physiology, v.117, p.913-922, 1998. Disponível em: <http://www.plantphysiol.org/ content/117/3/913.full.pdf+html >. Acesso em: 25 maio 2013.

WANG, K. et al. Maize transformation. In: BENNETZEN, J.L.; HAKE, S.C. Handbook of maize: genetics and genomics. Nova York: Springer, 2009. p.609-649.

ZHANG, H. et al. Stable integration of an engineered megabase repeat array into the maize genome. Plant Journal, v.70, p.357365, 2012. Disponível em: <http://www.ncbi.nlm.nih.gov/pubm ed/22233334>. Acesso em: 25 maio 2013. 